\title{
The Local Tourist Interest on Museum: A Study in Bandung, West Java
}

\author{
Tania Maria ${ }^{1}$, Diena M. Lemy ${ }^{2}$ \\ ${ }^{1,2}$ Pelita Harapan School of Hospitality and Tourism, Jakarta, Indonesia \\ 1Tania_maria96@yahoo.com, ${ }^{2}$ Diena.lemy@uph.edu
}

\begin{abstract}
Emerging number of local tourists visits to Bandung for recent years creating opportunities to develop more innovative tourist destinations, including museum. Therefore, this study seeks to understanding local tourists interests upon museum in Bandung. Data was collected from respondents using electronic questionnaires, mostly administered from surrounding cities, such as people who frequently travels weekend. The study shows that heritage tourism holds a great role in shaping tourists image of educational recreation experience. This research enhances understanding of tourism experience at museums, the potentials of museum business in the future, and could be used to improving tourism products and services in Bandung, West Java.
\end{abstract}

Keywords-Museum, travel, involvement, tourism, heritage tourism.

\section{INTRODUCTION}

The city of Bandung, founded in 1810 by the Dutch Governor-General Herman Willem Daendels, was initially led by R.A. Wiranatakusumah II. As one of the city getting through by the postal route (De Groote Postweg), Bandung plays an important role as a liaison for the surrounding area at that time. Bandung is also known as one of the major tourist destination cities on the island of Java. The city of Bandung has a variety of favorite tourist attractions that are visited by both local and foreign tourists. Bandung is one of the big cities in Indonesia that has a culture and history of interest to know about (Lutfiany, T., 2012). Historical tourism became one of the main advantages in Bandung due to having strong historical ties with the Dutch colonial government.

Tourist destinations that combine education and recreation is one of the popular destinations in Bandung. Especially for families who want to travel while providing memorable experiences for children, young adults who seek weekend activities, educational tours is one of the best option that can be enjoyed in a short time. Furthermore, the increasing number of residents must be accompanied by the availability of public spaces and tourist attractions that can be urban recreation destination. With the rising number of tourist arrivals in Bandung over the times push development and demand for labor and economic growth. From the result of a survey by Department of Tourism and Culture of West Jawa in 2015 until the year 2016, tourist visits to the city of Bandung continues to increase every year.

\section{TABLE I. LIST OF VISITOR TO ACCOMMODATIONS AND TOURIST DESTINATIONS IN BANDUNG (VISITORS DOCUMENTATION, 2016)}

\begin{tabular}{|c|c|c|c|c|c|c|}
\hline \multirow{2}{*}{ Year } & \multicolumn{2}{|c|}{$\begin{array}{l}\text { Total Visits to } \\
\text { Accommodations }\end{array}$} & \multirow{2}{*}{ Total } & \multicolumn{2}{|c|}{$\begin{array}{l}\text { Total Visits to Tourist } \\
\text { Destinations }\end{array}$} & \multirow{2}{*}{ Total } \\
\hline & $\begin{array}{l}\text { Foreign } \\
\text { Tourists }\end{array}$ & $\begin{array}{l}\text { Local } \\
\text { Tourists }\end{array}$ & & $\begin{array}{l}\text { Foreign } \\
\text { Tourists }\end{array}$ & $\begin{array}{c}\text { Local } \\
\text { Tourists }\end{array}$ & \\
\hline 2015 & 176.487 & 4.242 .294 & 4.418 .781 & 30.178 & 1.431 .290 & 1.461 .468 \\
\hline 2016 & 176.487 & 4.624 .621 & 4.801 .108 & 432.271 & 1.431 .290 & 1.863 .561 \\
\hline
\end{tabular}

Lists of museums in Bandung:

1. Museum of the Asian-African Conference

2. Museum Geology

3. Museum Sri Baduga 
4. Museum Pos Indonesia

5. Museum Wangit Mandala Siliwangi

6. Museum Barli

7. Museum Pendidikan Nasional

In terms of quantity, the museums in Bandung is still relatively few in number, and from the theme especially about history and heritage has not been dug deeper. Some museums tend to exhibit collections relating to Indonesian topics extensively. After reviewing the factors above, along with tourist destinations and the number of existing museums, it appears that museum is a tourist destination that has great potential of development in Bandung. Especially for tourists, families, and students in Bandung who want to experience heritage while enjoying the time to relax.

After understanding the background, the purposes of this study are consist of:

1. Analyzing and understanding local tourists behavior towards museum as tourism destination in Bandung.

2. Developing heritage tourism destinations in Bandung and Indonesia.

\section{LITERATURE REVIEW}

Definition of museum from International Council of Museum (ICOM, 2013) is a non profit, permanent institution in the service of society and its development, open to the public, which acquires, conserves, researches, communicates and exhibits the tangible and intangible heritage of humanity and its environment for the purposes of education, study and enjoyment.

Based on Government Regulation Number 66 Year 2015 About the Museum Article 1, paragraph 1 (2015) states the museum is an institution that serves to protect, develop, utilize the collection, and communicate it to the public.

Culture tourism is being considered as one of many aspects that play vital role in tourism. World Tourism Organization (Vaquer,M., 2015) states culture tourism consist of all aspect of tourism that can teach visitors about their past and inheritance as well as their contemporary lifestyles. Csapo (2015) clarify cultural based tourism as all the movements of people toward a specific cultural attraction outside their place of residence aims to gain new information and experience to satisfy their cultural needs.

According to Gruszczyriska (2016) culture can be reborn but the heritage of the culture (heritage) is not. Historical objects are highly vulnerable to various risks and it can be concluded that heritage is part of history if the monument disappears. Cultural heritage belongs to the people, so it is important to provide access to it.

Boylan, Patrick,J., and Woolard,V (2004) explains fundamental elements or principle which a museum must have in their operational. First principle is institutional standing of a museum. Museums are responsible for the tangible and intangible natural and cultural heritage. Governing bodies and those concerned with the strategic direction and oversight of museums have a primary responsibility to protect and promote this heritage as well as the human, physical and financial resources made available for that purpose Second is the environment, which greatly affect the sustainability of the museum. Museums and their collections should be available at certain hours and at reasonable and standardized periods to ensure the health, safety, and accessibility of visitors and employees. Third, security of a museum. The governing body should ensure appropriate security to protect collections against theft or damage in displays, exhibitions, working or storage areas and while in transit. Next is funding. In the process of funding the museum, it is divided into government sector or private sector, otherwise obtained through the museum activities. A good funding policy is required so museums do not abuse museum standards to seek excess profits. And last principle is human resources. Museum employees are very important resource of the museum. The management needs to ensure that every individual involved in the operation of a museum complies with the code of ethics and regulations in the museum. Novokhatko (Novokhatko, 2014) also defines modern concept of museum as a space for lifelong learning. Now that there are children, students, adults, and senior citizens among regular Internet users, museums are able to provide these different target audiences with special online programs, both educational and entertaining.Furthermore, Novokhatko insists that it is important for museums to plan programs, exhibitions, and even websites that play an important role in the process of delivering information. In addition the museum certainly can play a more active 
role in creating meaningful experience. The heart of the experience of visiting museums is the individual's ability to see and experience the real things in a meaningful physical context. The latest technologies, such as augmented reality, allow modern exhibits of interest to the public, but it is important to make an in-depth observation of the proper balance between the entertainment and educational functions of the museum (Novokhatko, 2014).

\section{METHODS}

\section{A. Data}

Data collection techniques are divided into primary and secondary data. Primary data collection was done by using questionnaire and observation technique. Respondent answers were collected in questionnaire by using google form, in order to obtained valid data from 290 respondents as supporting data research. For secondary data, taken from the library sources, internet or website, and reference scientific papers.

\section{B. Method}

Sekaran, Uma, Bougie, and Roger (2016: 242) states there are two method of sampling which are Probability Sampling and Nonprobability Sampling. Probability sampling is selected when the elements in the population have some known, nonzero chance or probability of being selected as sample subjects. Probability sampling designs are used when the representativeness of the sample is of importance in the interests of wider generalizability. While nonprobability sampling are the elements in the population do not have any probabilities attached to their being chosen as sample subjects. The sampling method being used is nonprobability sampling consist of purposive sampling and convenience sampling.

\section{RESULT AND DISCUSSION}

\section{A. Result}

From the table of questionnaire results can be seen that $70.7 \%$ of respondents are female and $29.3 \%$ are male. Based on the questionnaire results, it is known that $41 \%$ of respondents are under 20 years old, $54.1 \%$ of respondents are aged $>20-30$ years, $1.7 \%$ of respondents are aged $>30-40$ years, $1.7 \%$ of respondents are aged $>40-50$ year, and $1.4 \%$ of respondents aged $>50$ years.

Based on the questionnaire results, , 96.6\% of respondents are not married and 3.4\% are married. Based on the questionnaire results, it is known that as many as $29 \%$ of respondents are staying in Bandung, as many as $11 \%$ are staying in Bandung Regency, as much as $2.8 \%$ in Cimahi City, 27.9\% in Jakarta, 27.9\% in Tangerang, 7\% in Tangerang Selatan, 0.3\% in West Bandung District, 0.3\% in Bogor. Based on the questionnaire results, $20.7 \%$ of respondents are students, $68.6 \%$ are college students, $7.9 \%$ are employees, $0,7 \%$ are housewives, $0.3 \%$ are lecturers, $0.3 \%$ are pensionary, $0.3 \%$ are lecturer assistant, $0.3 \%$ are acupuncturist.

Based on the questionnaire results, $61.4 \%$ of respondents have $<\operatorname{Rp} 2.500 .000,00$ expenses per month, $31 \%$ have expenses $>\mathrm{Rp} 2.500 .000,00$ - Rp 5.000.000,00, 4.1\% have expenditures of $>\mathrm{Rp}$ $5.000 .000,00$ - Rp 7.500.000,00, 2.4\% have expenses> Rp 7.500.000,00 - Rp 10.000.000,00, $1 \%$ of respondents have expenses> Rp 10.000.000,00. 
TABLE II. DEMOGRAPHICS ITEMS FOR THE RESPONDENTS

\begin{tabular}{|c|c|c|c|}
\hline \multirow[b]{2}{*}{$\begin{array}{l}\text { Demographic } \\
\text { Items }\end{array}$} & \multicolumn{3}{|c|}{ Respondents } \\
\hline & Value & Total & $\begin{array}{l}\text { Percentage } \\
(\%)\end{array}$ \\
\hline & Male & 85 & 29,3 \\
\hline \multirow{2}{*}{ Gender } & Female & 205 & 70,7 \\
\hline & Subtotal & 290 & 100 \\
\hline \multirow[t]{6}{*}{ Age } & $\leq 20$ & 119 & 41 \\
\hline & $>20-30$ & 157 & 54,1 \\
\hline & $>30-40$ & 5 & 1,7 \\
\hline & $>40-50$ & 5 & 1,7 \\
\hline & $>50$ & 4 & 1,4 \\
\hline & Subtotal & 290 & 100 \\
\hline \multirow[t]{3}{*}{ Status } & Married & 10 & 3,4 \\
\hline & Not Married & 280 & 96,6 \\
\hline & Subtotal & 290 & 100 \\
\hline \multirow{9}{*}{ Area of Residence } & Bandung & 84 & 29 \\
\hline & West Bandung District & 1 & 0,3 \\
\hline & Bandung Regency & 32 & 11 \\
\hline & Cimahi & 8 & 2,8 \\
\hline & Jakarta & 81 & 27,9 \\
\hline & Tangerang & 81 & 27,9 \\
\hline & Bogor & 1 & 0,3 \\
\hline & South Tangerang & 2 & 0,7 \\
\hline & Subtotal & 290 & 100 \\
\hline \multirow{10}{*}{ Occupation } & Student & 60 & 20,7 \\
\hline & College Student & 199 & 68,6 \\
\hline & Employee & 23 & 7,9 \\
\hline & Housewife & 2 & 0,7 \\
\hline & Teacher & 2 & 0,7 \\
\hline & Lecturer & 1 & 0,3 \\
\hline & Pensionary & 1 & 0,3 \\
\hline & Lecturer assistant & 1 & 0,3 \\
\hline & Acupunturist & 1 & 0,3 \\
\hline & Subtotal & 290 & 100 \\
\hline \multirow{7}{*}{$\begin{array}{l}\text { Personal } \\
\text { Expenses per } \\
\text { Month }\end{array}$} & $\leq \mathrm{Rp} 2.500 .000,00$ & 178 & 61,4 \\
\hline & $>\operatorname{Rp} 2.500 .000,00-\mathrm{Rp}$ & 90 & 31 \\
\hline & $5.000 .000,00$ & & \\
\hline & $\begin{array}{l}>\operatorname{Rp} 5.000 .000,00-\mathrm{Rp} \\
7.500 .000,00\end{array}$ & 12 & 4,1 \\
\hline & $\begin{array}{l}>\operatorname{Rp} 7.500 .000,00-\mathrm{Rp} \\
10.000 .000,00\end{array}$ & 7 & 2,4 \\
\hline & $>\operatorname{Rp} 10.000 .000,00$ & 3 & 1 \\
\hline & Subtotal & 290 & 100 \\
\hline
\end{tabular}

Based on the results of the questionnaire, it is known there are $1.7 \%$ of respondents who visited the city of Bandung as much as $0-1$ times a month, $30.3 \%$ of respondents $1-2$ times, there are $2.4 \%$ of respondents as much as 3-4 times, there are $2.4 \%$ of respondents 5-6 times, there are $42.1 \%$ of respondents who live in Bandung, there are $18.6 \%$ of respondents who rarely visited Bandung, and $2.4 \%$ of respondents who never visited the city of Bandung.

Based on the questionnaire, $21.4 \%$ of respondents consider accessibility factor in visiting Bandung, then as many as $59.3 \%$ of respondents have consideration of tourism destination factors, as much as 72.15 considering culinary factors, as many as $9.3 \%$ of respondents consider historical and cultural factors, as many as $10.7 \%$ of respondents consider work factors, as many as $3.4 \%$ of respondents 
consider school factors, there are $10.3 \%$ of respondents considering residence factors, then as many as $1.4 \%$ of respondents consider family factors, as much as $0.7 \%$ of respondents consider and $0.7 \%$ of respondents consider the factor of the event, then $0.3 \%$ of respondents consider holiday factors, and as many as $0.3 \%$ of respondents consider church factors.

\section{TABLE III. MARKET CONDITION}

\begin{tabular}{|c|c|c|c|}
\hline \multirow[b]{2}{*}{ Questions } & \multicolumn{3}{|c|}{ Respondents } \\
\hline & Value & Total & $\begin{array}{c}\text { Percentage } \\
(\%)\end{array}$ \\
\hline \multirow{8}{*}{$\begin{array}{l}\text { How many times a } \\
\text { month do you visit } \\
\text { Bandung? }\end{array}$} & 0 -1 times & 5 & 1,7 \\
\hline & 1-2 times & 88 & 30,3 \\
\hline & 3-4 times & 7 & 2,4 \\
\hline & 5-6 times & 7 & 2,4 \\
\hline & Live in Bandung & 122 & 42,1 \\
\hline & Rarely & 54 & 18,6 \\
\hline & Never & 7 & 2,4 \\
\hline & Subtotal & 290 & 100 \\
\hline \multirow{14}{*}{$\begin{array}{c}\text { Which factors you } \\
\text { consider in visiting } \\
\text { Bandung? }\end{array}$} & Accessibility & 62 & 21,4 \\
\hline & Tourists Destination & 170 & 59,3 \\
\hline & Culinary & 209 & 72,1 \\
\hline & History and Culture & 27 & 9,3 \\
\hline & Work & 31 & 10,7 \\
\hline & School & 10 & 3,4 \\
\hline & Residence & 30 & 10,3 \\
\hline & Family & 4 & 1,4 \\
\hline & Hometown & 2 & 0,7 \\
\hline & Weather & 2 & 0,7 \\
\hline & Event & 1 & 0,3 \\
\hline & Vacation & 1 & 0,3 \\
\hline & Church & 1 & 0,3 \\
\hline & Subtotal & 290 & 100 \\
\hline \multirow{5}{*}{$\begin{array}{l}\text { Average times of } \\
\text { visiting museum } \\
\text { per month: }\end{array}$} & $1-2$ times & 284 & 97,9 \\
\hline & 3-4 times & 4 & 1,4 \\
\hline & 5-6 times & 0 & 0 \\
\hline & $>6$ times & 2 & 0,7 \\
\hline & Subtotal & 290 & 100 \\
\hline \multirow{10}{*}{$\begin{array}{c}\text { With whom do you } \\
\text { usually visit the } \\
\text { museum? }\end{array}$} & By oneself & 10 & 3,4 \\
\hline & Friend & 201 & 69,3 \\
\hline & Family & 61 & 21,0 \\
\hline & School Trip & 14 & 4,8 \\
\hline & Others & 4 & 1,4 \\
\hline & Subtotal & 290 & 100 \\
\hline & 1 hour & 131 & 45,2 \\
\hline & 2 hours & 95 & 32,8 \\
\hline & $>2$ hours & 40 & 13,8 \\
\hline & Subtotal & 290 & 100 \\
\hline
\end{tabular}




\begin{tabular}{|c|c|c|c|}
\hline \multirow{6}{*}{ Questions } & \multicolumn{3}{|c|}{ Respondents } \\
\hline & Value & Total & $\begin{array}{c}\text { Percentage } \\
(\%)\end{array}$ \\
\hline & 3-4 times & 4 & 1,4 \\
\hline & 5-6 times & 0 & 0 \\
\hline & $>6$ times & 2 & 0,7 \\
\hline & Subtotal & 290 & 100 \\
\hline \multirow{6}{*}{$\begin{array}{l}\text { With whom do you } \\
\text { usually visit the } \\
\text { museum? }\end{array}$} & By oneself & 10 & 3,4 \\
\hline & Friend & 201 & 69,3 \\
\hline & Family & 61 & 21,0 \\
\hline & School Trip & 14 & 4,8 \\
\hline & Others & 4 & 1,4 \\
\hline & Subtotal & 290 & 100 \\
\hline \multirow{16}{*}{$\begin{array}{l}\text { Where is the } \\
\text { location of the } \\
\text { museum that you } \\
\text { visit frequently? }\end{array}$} & Bandung & 132 & 45,5 \\
\hline & Jakarta & 169 & 58,3 \\
\hline & Tangerang & 7 & 2,4 \\
\hline & Bali & 28 & 9,7 \\
\hline & Malang & 1 & 1,4 \\
\hline & Singapore & 3 & 1,0 \\
\hline & Yogyakarta & 4 & 1,4 \\
\hline & Palembang & 1 & 0,3 \\
\hline & Lampung & 1 & 0,3 \\
\hline & Bogor & 1 & 0,3 \\
\hline & China & 1 & 0,3 \\
\hline & Malaysia & 1 & 0,3 \\
\hline & Thailand & 1 & 0,3 \\
\hline & Jepang & 1 & 0,3 \\
\hline & Other & 10 & 3,4 \\
\hline & Subtotal & 290 & 100 \\
\hline \multirow{6}{*}{$\begin{array}{c}\text { Ticket prices which } \\
\text { you are willing to } \\
\text { spend when visiting } \\
\text { a museum: }\end{array}$} & $<\operatorname{Rp} 25.000,00$ & 164 & 56,6 \\
\hline & $\begin{array}{c}>\operatorname{Rp} 25.000,00-\mathrm{Rp} \\
50.000,00\end{array}$ & 105 & 36,2 \\
\hline & $>$ >Rp $50.000,00-R p$ & 11 & 3,8 \\
\hline & $\begin{array}{c}>\mathrm{Rp} 75.000,00-\mathrm{Rp} \\
100.000,00\end{array}$ & 4 & 1,4 \\
\hline & $>\operatorname{Rp} 100.000,00$ & 6 & 2,1 \\
\hline & Subtotal & 290 & 100 \\
\hline \multirow{13}{*}{$\begin{array}{c}\text { Which factors are } \\
\text { into your } \\
\text { considerations } \\
\text { when visiting a } \\
\text { museum? }\end{array}$} & Types of Museum & 152 & 52,4 \\
\hline & Museum Concepts & 210 & 72,4 \\
\hline & Museum Collections & 182 & 62,8 \\
\hline & Price & 75 & 25,9 \\
\hline & Accessibility & 84 & 29,0 \\
\hline & Knowledge and Insight & 168 & 57,9 \\
\hline & Instagramable & 3 & 1,0 \\
\hline & Art & 2 & 0,7 \\
\hline & Campus Task & 1 & 0,3 \\
\hline & Environmental Condition & 1 & 0,3 \\
\hline & Tourism & 1 & 0,3 \\
\hline & Entertainment & 1 & 0,3 \\
\hline & Subtotal & 290 & 100 \\
\hline \multirow{5}{*}{$\begin{array}{l}\text { How long did you } \\
\text { spend when visiting } \\
\text { a museum? }\end{array}$} & $<1$ hour & 24 & 8,3 \\
\hline & 1 hour & 131 & 45,2 \\
\hline & 2 hours & 95 & 32,8 \\
\hline & $>2$ hours & 40 & 13,8 \\
\hline & Subtotal & 290 & 100 \\
\hline
\end{tabular}


Based on the results of the questionnaire, as many as $97.9 \%$ of respondents visited the museum on average 1-2 times a month, as many as $1.4 \%$ of respondents visited the museum an average of $3-4$ times, and as much as $0.7 \%$ average $5-6$ times.

Based on the results of the questionnaire, as many as $3.4 \%$ of respondents visited the museum itself, as many as $69 \%$ of respondents visited the museum together with friends, as many as $21 \%$ of respondents visited the museum along with the family, as many as $4.8 \%$ of respondents visited the museum with school, $4 \%$ of respondents visited respondents along with others. The majority of respondents visited the museum together with friends.

Based on the results of the questionnaires, $58.3 \%$ of respondents frequently visited museums in Jakarta, as many as $45.5 \%$ of respondents visited the museum in Bandung, as many as $2.4 \%$ of respondents visited the museum in Tangerang, as many as $9.7 \%$ of respondents visited the museum in Bali , as many as $1.4 \%$ respondents in Yogyakarta, as much as $1 \%$ of respondents in Singapore, $0.3 \%$ of respondents in Malaysia, and $0.3 \%$ respondents in Lampung, $0.3 \%$ of respondents visited museums in China, as much as 2, $1 \%$ of respondents in Malang, $0.3 \%$ of respondents in Bogor, as much as $0.3 \%$ of respondents in Japan, as much as $3.4 \%$ in other countries.

Based on the questionnaire results, 56.6\% of respondents are willing to spend Rp 25.000,00 for museum ticket prices, as much as $36.2 \%$ of respondents are willing to pay a fee of $>\mathrm{Rp} 25.000,00$ Rp 50.000,00, as much as 3.8\% respondents willing to pay> Rp 50.000,00 - Rp 75.000,00, 1.4\% of respondents willing to spend> Rp 75.000,00 - Rp 100.000,00, and as much as $2.1 \%$ of respondents willing to spend> Rp 100.000,00.

Based on the results of the questionnaires, $52.4 \%$ of respondents consider the type of museum factor when visiting, as much as $72.4 \%$ of respondents consider the concept factor museum, as many as $62.8 \%$ of respondents consider the museum collection factor, there are $25.9 \%$ of respondents consider the price factor, $29 \%$ of respondents consider accessibility factor, then there are $57.9 \%$ of respondents considering knowledge and insight factor, $1 \%$ of respondents consider instagramable factors, as much as $0.7 \%$ of respondents consider the art factor, as many as $0.3 \%$ of respondents consider campus task factors, as much as $0.3 \%$ of respondents consider environmental factors, as much as $0.3 \%$ of respondents consider tourism factors, as much as $0.3 \%$ of respondents consider the entertainment factor.

Based on the results of the questionnaire, it was found that $8.3 \%$ of respondents spent $<1$ hour in the museum, as many as $45.2 \%$ of respondents spent 1 hour, $32.8 \%$ of respondents spent 2 hours, $13.8 \%$ spend $>2$ hours.

TABLE IV. RESPONDENTS INTEREST IN BUILDING NEW MUSEUM DESTINATION

\begin{tabular}{|c|c|c|c|}
\hline \multirow[b]{2}{*}{ Question } & \multicolumn{3}{|c|}{ Respondents } \\
\hline & Value & Total & Percentage (\%) \\
\hline If a history museum of Bandung built & Yes & 256 & 88,3 \\
\hline $\begin{array}{l}\text { in the area of Jalan Riau, Bandung } \\
\text { that displays interesting audio visual }\end{array}$ & No & 34 & 11,7 \\
\hline $\begin{array}{c}\text { and installations, will you be interested } \\
\text { in visiting? }\end{array}$ & Subtotal & 290 & 100 \\
\hline
\end{tabular}

Based on the results of questionnaires, as many as $88.3 \%$ of respondents interested in visiting newly opened museum, while $11.7 \%$ of respondents are not interested in visiting the museum. 
TABLE V. DESCRIPTION OF ANSWERS (PART ONE)

\begin{tabular}{|c|c|c|c|}
\hline Values & Description & Total & $\begin{array}{l}\text { Percentage } \\
\quad(\%)\end{array}$ \\
\hline \multirow{37}{*}{ Yes } & Artistic & 1 & 0,3 \\
\hline & Authentic & 1 & 0,3 \\
\hline & Interesting audio visual and installations & 7 & 2,4 \\
\hline & Bandung is second home & 1 & 0,3 \\
\hline & Has never been to a museum & 2 & 0,7 \\
\hline & Bored of shopping centre & 1 & 0,3 \\
\hline & $\begin{array}{l}\text { A way to know Bandung more deeply that has been packed in one } \\
\text { place that provides all forms of explanation and a reminder for } \\
\text { history of the city itself }\end{array}$ & 1 & 0,3 \\
\hline & Supporting area & 6 & 2,1 \\
\hline & New tourist destination & 25 & 8,6 \\
\hline & Photography & 5 & 1,7 \\
\hline & Want to know more about history of Bandung. & 9 & 3,1 \\
\hline & Interesting architecture & 2 & 0,7 \\
\hline & $\begin{array}{l}\text { Bandung is one of the famous cities that have many stories in it. Its } \\
\text { popularity is not swallowed by time. If the history of Bandung being } \\
\text { told using technology, there will be many people, even tourists from } \\
\text { outside the region or country that will be interested to know }\end{array}$ & 1 & 0,3 \\
\hline & $\begin{array}{l}\text { It is rare to find museum with audio visual and technology in } \\
\text { Bandung }\end{array}$ & 8 & 2,8 \\
\hline & $\begin{array}{l}\text { Makes the slogan "history can come back to life in the museum" be } \\
\text { real. }\end{array}$ & 1 & 0,3 \\
\hline & Love to visit museum & 16 & 5,5 \\
\hline & Interested in museums and installations inside & 5 & 1,7 \\
\hline & It is rare to find people visiting museums & 3 & 1,0 \\
\hline & Easily accessed location & 6 & 2,1 \\
\hline & Learning cultural and historical knowledge & 19 & 6,6 \\
\hline & Interesting & 36 & 12,4 \\
\hline & Make use of spare time & 1 & 0,3 \\
\hline & $\begin{array}{l}\text { Historic museums with good governance and good audio visual } \\
\text { design are the attractions that are needed for the community. } \\
\text { Preserving culture in a modern way is the right strategy to attract } \\
\text { people }\end{array}$ & 1 & 0,3 \\
\hline & Modern museum is needed today for young generation & 3 & 1,0 \\
\hline & Comfortable & 1 & 0,3 \\
\hline & Art observation & 2 & 0,7 \\
\hline & Curious & 21 & 7,2 \\
\hline & New attraction for tourists & 14 & 4,8 \\
\hline & Recreation & 5 & 1,7 \\
\hline & Educational facitilies & 2 & 0,7 \\
\hline & Strategic & 16 & 5,5 \\
\hline & Loves history & 12 & 4,1 \\
\hline & Interested in different atmosphere & 10 & 3,4 \\
\hline & $\begin{array}{l}\text { Located in a tourist area filled with factory outlets and culinary } \\
\text { centers }\end{array}$ & 6 & 2,1 \\
\hline & Good traffic & 1 & 0,3 \\
\hline & Unique & 5 & 1,7 \\
\hline & Subtotal & 256 & 88,3 \\
\hline
\end{tabular}


TABLE V. DESCRIPTION OF ANSWERS (PART TWO)

\begin{tabular}{llcc}
\hline Values & \multicolumn{1}{c}{ Description } & Total & $\begin{array}{c}\text { Percentage } \\
\mathbf{( \% )}\end{array}$ \\
\hline & Traffic jam & 4 & 1,4 \\
Rarely visit Bandung & 5 & 1,0 \\
Far & 5 & 1,7 \\
Dislike museums & 3 & 1,7 \\
Less interested in heritage & 1 & 1,0 \\
Museums in difficult position to compete & 1 & 0,3 \\
Not interestes & 1 & 0,3 \\
Not important & 1 & 0,3 \\
Not famous & 1 & 0,3 \\
Busy in learning & 2 & 0,3 \\
Having more interest in culinary and shopping & 1 & 0,7 \\
Bored & 5 & 0,3 \\
Because the area is better known as a tourist shopping area. & 1,7 \\
Perhaps more it will be more appropriate if built in places that & & \\
have many historical buildings such as Asia Afrika or Braga & & \\
No & 1 & 0,3 \\
Because in the history of Bandung there is no major event & & \\
except Bandung Lautan Api and Bandung is a volcanic lake. & & \\
Then, the DNA of this city is not history but tourism such as & & \\
shopping, eating, vacation, nature, and others & 34 & 11,7 \\
Subtotal & & \\
& &
\end{tabular}

Based on the results of the questionnaire above, it can be seen that the respondents who are interested in giving reasons ranging from $12.4 \%$ respondents answered interesting, $8.6 \%$ respondents answered new tourist destination, $7.2 \%$ respondents answered curious, $6.6 \%$ learning of historical and cultural knowledge, $5.5 \%$ of respondents gave strategic reasons, $5.5 \%$ respondents answered because. they love to go to the museum, $4.8 \%$ respondents answered new attraction for tourists, $4.1 \%$ respondents like history, and 3,4\% of respondents answered interested in different atmosphere.

Meanwhile, as many as $1.7 \%$ of respondents who are not interested answered that the area is better known as a tourist shopping area so it will be more appropriate if built in places that have many historical buildings such as Asia Afrika or Braga. Then, $1.7 \%$ of respondents said it is far, $1.7 \%$ of respondents do not like the museum, as many as $1.4 \%$ of respond traffic jam, $1 \%$ of respondents rarely visit Bandung, and $1 \%$ of respondents are not interested in history and heritage.

According to Morrison, product is the range of service and facilities (product/service mix) a hospitality and travel organization provides to customers. Products are some of the range of products and services provided to customers (Morrison, 2010). Products offered by museum is a ticket to enjoy the collection of various photographs of Bandung history, relics, videos, and infographic information about the history of Bandung. Museum differentiation lies in the presentation of historical material and the use of virtual reality goggles technology to provide a new experience in visiting museums.

Based on the data table above, there are 114 respondents (39.31\%) stated strongly agree with the establishment of the museum with an interesting historical concept. A total of 121 respondents $(41.72 \%)$ strongly agree if the museum displays diorama and attractive visual design. There are 112 respondents (38.62\%) agree if there is a collection of photographs and installations of history of Bandung. 
TABLE VI. MUSEUM PRODUCTS

\begin{tabular}{|c|c|c|c|}
\hline \multirow{2}{*}{ Questions } & \multicolumn{3}{|c|}{ Respondent } \\
\hline & Values & Total & Percentage $(\%)$ \\
\hline \multirow{6}{*}{ The museum has an interesting historical concept } & Strongly disagree & 5 & 1,72 \\
\hline & Disagree & 8 & 2,76 \\
\hline & Somewhat disagree & 14 & 4,83 \\
\hline & Somewhat agree & 44 & 15,17 \\
\hline & Agree & 105 & 36,21 \\
\hline & Strongly Agree & 114 & 39,31 \\
\hline \multirow{9}{*}{$\begin{array}{c}\text { The museum features dioramas and attractive } \\
\text { visual designs. }\end{array}$} & Subtotal & 290 & 100 \\
\hline & Strongly disagree & 4 & 1,38 \\
\hline & Disagree & 7 & 2,41 \\
\hline & Somewhat disagree & 12 & 4,14 \\
\hline & Somewhat agree & 44 & 15,17 \\
\hline & Agree & 102 & 35,17 \\
\hline & Strongly Agree & 121 & 41,72 \\
\hline & Subtotal & 290 & 100 \\
\hline & Strongly disagree & 3 & 1,03 \\
\hline \multirow{5}{*}{$\begin{array}{l}\text { There is a collection of photographs and } \\
\text { installations of history of Bandung. }\end{array}$} & Disagree & 9 & 3,10 \\
\hline & Somewhat disagree & 19 & 6,55 \\
\hline & Somewhat agree & 44 & 15,17 \\
\hline & Agree & 112 & 38,62 \\
\hline & Strongly Agree & 103 & 35,52 \\
\hline \multirow{8}{*}{$\begin{array}{l}\text { There are virtual reality goggles (special glasses for } \\
\text { viewing and enjoying 3D video display) featuring } \\
\text { the uniqueness of Bandung }\end{array}$} & Subtotal & 290 & 100 \\
\hline & Strongly disagree & 8 & 2,76 \\
\hline & Disagree & 7 & 2,41 \\
\hline & Somewhat disagree & 13 & 4,48 \\
\hline & Somewhat agree & 50 & 17,24 \\
\hline & Agree & 92 & 31,72 \\
\hline & Strongly Agree & 120 & 41,38 \\
\hline & Subtotal & 290 & 100 \\
\hline \multirow{6}{*}{$\begin{array}{l}\text { There is a special area to enjoy periodic exhibits on } \\
\text { specific themes every few months. }\end{array}$} & Strongly disagree & 2 & 0,69 \\
\hline & Disagree & 13 & 4,48 \\
\hline & Somewhat disagree & 16 & 5,52 \\
\hline & Somewhat agree & 40 & 13,79 \\
\hline & Agree & 110 & 37,93 \\
\hline & Strongly Agree & 109 & 37,59 \\
\hline \multirow{8}{*}{$\begin{array}{c}\text { There is an auditorium featuring flashbacks of } \\
\text { history of Bandung and West Java cultural } \\
\text { performances. }\end{array}$} & Subtotal & 290 & 100 \\
\hline & Strongly disagree & 2 & 0,69 \\
\hline & Disagree & 11 & 3,79 \\
\hline & Somewhat disagree & 18 & 6,21 \\
\hline & Somewhat agree & 42 & 14,48 \\
\hline & Agree & 109 & 37,59 \\
\hline & Strongly Agree & 108 & 37,24 \\
\hline & Subtotal & 290 & 100 \\
\hline
\end{tabular}

Then, as many as 120 respondents $(41.38 \%)$ strongly agree with the existence of virtual reality goggles (special glasses to see and enjoy the 3D video display) featuring the uniqueness of Bandung. There are 110 respondents (37.93\%) agree if there is a special area to enjoy periodic exhibitions with 
certain themes every few months. A total of 109 respondents (37.59\%) agree if there is an auditorium featuring a flashback video of history of Bandung and West Java cultural performances.

TABLE VII. MEAN, STD. DEVIATION

\begin{tabular}{clccc}
\hline NO & \multicolumn{1}{c}{ Description } & Mean & $\begin{array}{c}\text { Std. } \\
\text { Deviation }\end{array}$ & N \\
\hline 1 & The museum has an interesting historical concept & 4,99 & 1,125 & 290 \\
2 & The museum features dioramas and attractive visual designs. & 5,06 & 1,083 & 290 \\
3 & $\begin{array}{l}\text { There is a collection of photographs and installations on the } \\
\text { history of Bandung. }\end{array}$ & 4,94 & 1,102 & 290 \\
4 & $\begin{array}{l}\text { There are virtual reality goggles (special glasses for viewing } \\
\text { and enjoying 3D video display) featuring the uniqueness of }\end{array}$ & 4,97 & 1,195 & 290 \\
& $\begin{array}{l}\text { Bandung } \\
\text { There is a special area to enjoy periodic exhibits on specific } \\
\text { themes every few months. }\end{array}$ & 4,97 & 1,119 & 290 \\
6 & $\begin{array}{l}\text { There is an auditorium featuring flashbacks of history of } \\
\text { Bandung and West Java cultural performances. }\end{array}$ & 4,96 & 1,105 & 290 \\
\hline
\end{tabular}

All the data represented from product aspect of questionnaire were processed in SPSS to determine the mean and standard deviation value. The number of mean in table shown above providing results of mean range around 5,00 which represents validity of the answers from questionnaire.

\section{B. Discussion}

From these results, it can be analyzed that the main target market of the museum is women, while men are secondary target market. Thus it is expected that women are able to encourage men to visit the museum in this case such as spouse, family, or friends. The majority of respondents aged 20-30 years and unmarried status. These results can influence the determination of programs and activities in the museum. The level of expenditure of respondents indicates the state of the economy and purchasing power of products offered by the museum. From the questionnaire data, it appears that the majority of respondents have expenditures that tend to be low.

Furthermore, respondents are divided into citizens of Bandung and area such as Jakarta and Tangerang, which shows the visiting level to Bandung tends to be high every month and year. Respondents considerations in visiting of Bandung are culinary, tourist destinations, and accessibility. This supports the statement that Bandung is a favorite tourist destination and facilities such as accessibility and tourist attractions are very influential in attracting local tourists. Respondents visited museum 1-2 times per month showing concern for museums and the need for recreation every month. Then, respondents choose to visit museum with friends which will affect the promotional strategy undertaken by museum. Museum should be creative in products packaging and promotions to potential visitors, especially the younger generation.

The majority of respondents chose museums in Jakarta and Bandung as the destination they visited frequently. This data shows museums in Bandung are quite popular and routinely visited by tourists.

Although the level of expenditure of respondents tend to be low, but respondents are willing to pay for tickets up to maximum of Rp 100,000.00. It appears that the respondents noticed the interesting quality and packing of concept can increase the level of purchasing. Factors that affect the respondents are quite diverse and it is certain that every aspect of the museum impacts the experience of every tourist. Also varying respondents' time of visits shows an interest in the material that the museum offers and encourages the museum to provide and enhance the convenience for visitors.

From product statements that have been prepared, respondents approve products offered by the museum. This will affect sales and developing more innovation to encourage visits from tourists. Products with attractive technology and designs are considered to be more suited to the lifestyles of urban people, thus tending to increase interest in the material showcased by museum. 


\section{CONCLUSION}

This study was conducted to determine the relationship of community interest in Bandung to the existing and potential newly opened museum. From the research that has been done, it can be concluded that the level of public interest in the museum in Bandung is quite high. The museum business plan to be established gets appreciation from the community and certainly shows the needs of the community for educational tourism destinations in the context of the museum. It should be further investigated whether the establishment of the latest technology-based museum is appropriate and in accordance with the culture and lifestyle of the community that affect the level of visits to the Museum. This will be useful for the development of tourism especially in history in Bandung and West Java.

Acknowledgement. This research is fully supported by Pelita Harapan School of Hospitality and Tourism.

\section{REFERENCES}

Lutfiany, and Trina. (2012).Bandoeng Tempo Doeloe. School of Arts and Design ITB. (2), 1.

Visitors Documentation - Departments of Tourism and Culture West Java Region. (2016).

International Council of Museums.(2013).Code of Ethics: ICOM Code of Ethics for Museums. ICOM, 1.

Government Regulation Number 66 Year 2015 About the Museum Article 1, paragraph 1.

Vaquer, and Margalida.(2015).Affiliate Members Global Reports, Volume Twelve - Cultural Routes and Itineraries ," UNWTO. 37.

Csapo, and Janos.(2012).Strategies for Tourism Industry - Micro and Macro Perspectives. Intech.

Gruszczyriska, and Joanna.2016.Heritage for Future: Heritage in Transformation Cultural Heritage Protection in XXI Century - Problems, Challenges, Predictions. Drukarnia ALF-GRAF.

Boylan, Patrick J., and Woolard, Vicky.(2004).Running a Museum: A Practical Handbook.ICOM.

Novokhatko, and Ksenia.(2014).New Information and Communication Technologies for Museum Development: Policy Brief. ICOM Russia.

Sekaran, Uma, Bougie, and Roger.2016. Research Methods for Business: A Skill-Building Approach Seventh Edition, John Wiley.

Morrison, and Alastair. M. 2010.Hospitality \& Travel Marketing Fourth Edition. Delmar Thomson Learning Inc. 